\title{
Presentation of the "Beneficial Owner" Rule and Its Application in International Anti-tax Avoidance
}

\author{
Qing Xu \\ School of Accounting \\ Fujian Jiangxia University \\ Fuzhou, China 350108
}

\author{
Ling Yuan \\ School of Accounting \\ Fujian Jiangxia University \\ Fuzhou, China 350108
}

\begin{abstract}
With the development of global international exchanges and international trade, China has officially signed more than 100 tax treaties to avoid international double taxation. These tax treaties are conducive to the introduction of foreign capital and the development of foreign trade, but it is accompanied by an increasingly serious international tax avoidance issue. To this end, the "beneficial owner" rule in the anti-tax avoidance clause has become the focus of the practice community.
\end{abstract}

Keywords-benefit owners; international anti-tax avoidance; substance

\section{INTRODUCTION}

With the development of global international exchanges and international trade, by the end of October 2018, China had formally signed 109 tax agreements, 102 of which had entered into force. In order to avoid international double taxation, China has set preferential tax rates on the withholding tax rate on dividends, interest and royalties in the tax treaty, using the model OECD Agreement as the reference system. According to the provisions of China's Enterprise Income Tax Law, if a non-resident enterprise does not set up an institution or place in China, or if the income obtained by the establishment of an institution or place has no practical connection with the institution or place it has established, it shall pay the enterprise income tax on the income derived from the territory of China. These forms include dividends, interest, royalties and income from the transfer of property. For non-resident enterprises that meet the above conditions, a withholding income tax rate of $10 \%$ is against the income obtained by non-resident enterprises that meet the above conditions in accordance with Article 3, paragraph 3 of the Enterprise Income Tax Law. However, in tax agreements or arrangements signed in our country and other countries or regions to avoid double taxation, a lower tax rate may be set for dividends, interest, royalties, and income from the transfer of property. For example, in the tax treaty between our country and Kuwait, the withholding income tax rate on interest is only 5 per cent. These tax agreements are conducive to the introduction of foreign capital and the development of foreign trade, accompanied by a growing problem of international tax avoidance. To this end, the anti-avoidance clause "beneficial owner" clause has become the focus of the practical circles.

\section{THE INTRODUCTION OF THE CONCEPT OF "BENEFICIAL OWNERS"}

Any regulation is introduced with its legislative purpose. The most direct purpose is generally threefold. One is to solve what, such as the emergence of new business models have to be regulated by new documents, second, to encourage the development of an industry to get a regulatory point of preference, and the third is to prevent anything, such as a policy played by smart people to get a rule prohibited abuse to control.

So why introduce the concept of "beneficial owner"? "Beneficial owner" is a concept that often appears in international tax treaties, and it first appears in 1945, article 3, paragraph 2 (d), of the US-UK Agreement on the Avoidance of Double Taxation of Inheritance Tax: "Determines the shares or shares of a non-state company (including receipts for temporary stock held by the beneficial owner, What country shall the shares managed by the agent belong to the state in which the company shall be physically incorporated or established as the state of which it shall be." Subsequently, there is often a "beneficial owner" clause in international tax treaties that provides that when the recipient of dividends, interest and royalties is the beneficial owner, it may enjoy withholding income tax benefits from the other Party under the bilateral tax treaty. Through this concept, it is known that "beneficial owners" can enjoy benefits under a certain tax agreement.

It is thus clear that the concept of "beneficial owners" has emerged to prevent the misuse of preferences in tax treaties. The signing of a tax treaty between the two companies must have been for mutual benefit. That is, State A and Country B signed a tax agreement, State A hope signing for the ultimate benefit of the People B, Country B hope severing the ultimate benefit of the People A, and do not want to be used by any form of third party. The ultimate beneficiary is the "beneficial owner" in the tax code. Take the tax agreement between the two countries, for example, if State B receives the concession from State A and transfers the benefits directly to State $C$, then the real beneficiary for State A is State C rather than The State B, which was originally designed. Therefore, at the tax law level, there is a need to impose strict restrictions on the identification of "beneficial owners", taking into account what may happen in various 
business and transaction altogether, which is a problem that must be addressed by tax authorities in each country.

\section{EVOlution OF THE "BENEFIT FOR ALL" RULE}

\section{A. Sorting out the Tax Laws and Regulations of "Beneficial Owners" in China}

China's "beneficial owners" tax regulations The State Administration of Taxation has issued a number of regulations and interpretations for the recognition of "beneficial owners". In 2009, the State Administration of Taxation issued a Notice on How to Understand and Identify "Beneficial Owners" in The Tax Agreement (Irs Letter No. 601) (hereinafter referred to as "Beneficial Owners") (hereinafter referred to as "Beneficial Owners") and listed seven conditions for the identification of "beneficial owners", In guiding the tax authorities to carry out all the recognition practice of benefit is vague, operability is not strong. Since then, in 2012, the State Administration of Taxation issued a "notice on the identification of "beneficial owners" in the tax agreement (The State Administration of Taxation Announcement No. 30 of 2012, hereinafter referred to as Proclamation No. 30), which provides for the judgment of "beneficial owners" reference in article 601 to make a more detailed list of the interpretation, and standardizes" Beneficiaries" identification procedures. As No. 601 and Proclamation 30 still cause dispute more controversy and difficulties in the practice of tax law, the State Administration of Taxation subsequently issued in 2013 the Opinions on the Treatment of the Case of the Benefit holders of the Implementation of the Dividend Clauses of the Mainland and Hong Kong Tax Arrangements by the State Administration of Taxation of Hubei and other Provinces and Cities (General Tax Letter , 2013) 165, 165), to further guide the "beneficial owner" identification practice. Subsequently, with changes in the macroeconomic environment and economic policy, the implementation of the "beneficial owners" identification and inspection of the application of tax treaties weakened and then strengthened until February 3, 2018, when the State Administration of Taxation issued the Bulletin on issues related to "beneficial owners" in tax agreements. (The State Administration of Taxation announced No. 9 of 2018, hereinafter referred to as "Announcement No. 9") and interpretation, the 601 and 30 announcements have been substantially modified, the overall replacement of 601 and 30, so that China's "beneficial owners" of the ruling rules have been further improved.

\section{B. Differences Between China and Foreign Countries as Determined by "Beneficial Owners"}

Unlike countries' such as the OECD's tax treaty model and the common law system, which define the concept of "beneficial owner" through jurisprudence, China directly gives the definition and scope of application of beneficial owners through the domestic tax regulations. The case rules of the common law system have dynamically brought the scope of application of "beneficial owners" to a dynamic situation, and judicial authorities can make a case-by-case decision based on reality and experience in order to avoid tax treaties from adapting to emerging tax avoidance practices.
However, China's statutory law system is based on the existing provisions to adjudicate, in order to alleviate the law lag behind in the reality of the drawbacks, before the new situation has not yet appeared, China's tax laws and regulations through the definition and listing of adverse factors to expand the scope to the maximum can play a role in preventing the abuse of tax agreements. Announcement No. 601 and 30 were replaced by Announcement No. 9, which absorbed and drew on the results of the international tax practice and the OECD tax base erosion and profit transfer sixth action plan, which is the basic document of the concept and identification criteria of the beneficial owners of the tax authorities in China. Compared with the OECD tax treaty model and the relevant comments and revised discussions, there are still many obvious differences.

First, with regard to the determination of "beneficial owners", domestic tax legislation has always been a substantive standard. Article 2, paragraph 2, of Proclamation No. 9: "The business activities carried out by the applicant shall not constitute substantive business activities." Substantive business activities include activities such as manufacturing, distribution and management. Whether the business activities carried out by the applicant are substantial shall be determined on the basis of the functions performed in practice and the risks incurred" as the determination factors that are not conducive to the identity of the beneficial owner. The criteria for determining substantive business activities are the main criteria for determining the identity of beneficial owners in the domestic tax practice.

Second, the OECD model and notes exclude only qualified conduit companies from beneficial ownership. In the case of a conduit company, only a conduit company which has very limited rights over the proceeds received and is in fact acting as a trustee or executor for the benefit of an interested party shall be denied the beneficial owner status. Announcement No. 9 is deleted, and 601 agents in this paper, such as the catheter does not belong to the provisions of the "beneficial owner", pay more attention to the company's articles of association, the company's financial statements, capital flow to the record, the decision of the board of directors of the board of directors meeting record, and human and material resources situation, the relevant expenses, functions and risk-taking, loan contract, license to use or transfer contract, certificate of patent registration certificate, and the copyright. To determine whether it is the case of "receiving income on behalf of an agent" as stipulated in article 6 of this notice, analysis shall be made according to the agency contract or the designated collection contract. Announcement 9 excludes beneficial owners beyond conduit companies and removes the definition of conduit companies, emphasizing the principle of substance over form.

Third, as for the scope of "beneficial owner" control, the OECD model and notes emphasize that the identification of beneficial owner should focus on the payee's control and control over the relevant income, but not the basic property and rights of the income. Announcement No. 9 is based on the concept definition of "beneficial owner refers to the person who has the right of ownership or control over the rights or property derived from the income or the income", 
emphasizing the continuity of the equity held by the beneficial owner and the relatively complete right of control over the income.

Fourth, with regard to the concept and definition of "beneficial owner", the OECD model and notes stress that the concept of "beneficial owner" should have the meaning of international law, independent of the domestic law of the contracting states and not applicable to the special or general anti-tax avoidance rules in domestic law. According to notice no. 9, even if the applicant has the beneficial owner status, the tax authorities can still deny the applicant's tax treaty treatment by using the main purpose test provisions in the tax treaty or the general anti-tax avoidance rules stipulated by domestic tax laws. This judgment of "substance over form" is an anti-tax avoidance principle stipulated in the domestic tax laws of many countries. It gives tax authorities of contracting countries more discretion in determining the beneficial owner, even including the power to redefine transaction matters. Therefore, in the beneficial owner decided that issues apply "substance over form" principle of this kind of general anti-avoidance, its result will cause the tax treaty benefit all concept specific against the abuse of this agreement rules and other special or general inverse suspension is difficult to define the limits of each other, make the beneficial owner concept generalization as a general anti-avoidance rules. This is in contrast to the OECD model and notes that the beneficial owner concept clause is only a special anti-tax avoidance rule with limited functions and should not be interpreted or treated as a general anti-tax avoidance concept or rule.

\section{ANALYSIS OF TYPICAL INTERNATIONAL ANTI-TAX AVOIDANCE CASES JUDGED BY "BENEFICIAL OWNER"}

Beneficiaries are essential for enterprises to enjoy the treatment of tax agreements. From the typical case analysis, the identity of the beneficial owner is no, generally there are the following three reasons.

\section{A. The Criteria for Determination Is Not Sure, and the Hidden Dangers of the Organizational Structure Are Greater}

With the increasing number and types of cross-border trade, some multinational enterprise groups build different organizational structures in their tax jurisdictions in order to reduce the overall tax burden of the group. Some enterprises are not sure about the identification standard of beneficiary owners in our country, and adopt radical tax planning, which leads to the existence of great tax-related hidden dangers in the organizational structure. In the follow-up administration of tax treaty carried out by the competent tax authorities in China, the applicant was found to have abused the tax treaty and was ultimately unable to enjoy the preferential treatment related to the tax treaty.

\section{B. Paying Attention to the Form of Contempt for Substance as the Risk of Playing Side Ball Is Higher}

Tax agreement is the main tool to divide tax jurisdiction and guarantee the fairness of the international tax environment. China's tax treaty network is extensive, and there are some differences between the tax agreements signed between various countries or regions. Some multinational enterprises in pursuit of transnational tax revenue, in the tax treaty network more developed countries or regions set up middle-tier companies, but no business substance, only to formally meet the requirements of the agreement, through the way of playing the edge ball to enjoy the tax treaty treatment. In tax collection, the risk of playing the edge ball is higher, the less is denied the identity of the beneficial owner, and the heavy will be anti-avoidance investigation.

\section{The Benefits and Risks Do Not Match Very Well, and the Tables Do Not Attract Attention}

Multinational enterprises often build investment companies in low-tax countries or regions to implement control over domestic enterprises. As an applicant, the investment company applies to enjoy the tax agreement signed between the country of the investment company and China, so as to reduce the withholding tax burden on dividends and dividends distributed by Chinese companies abroad. However, some offshore investment companies have fewer registered capital and staffing, and it is difficult to match the huge dividends they receive. And the investment company to the domestic company's equity to bear very little risk, but to obtain a large amount of income, resulting in income and risk mismatch, easy to attract the attention of tax authorities.

\section{THE NORMS OF THE "BENEFICIAL OWNER" DETERMINATION}

Norms for the determination of "beneficial owners" In the concept of tax law, "beneficial owner" can be understood as the "ultimate beneficiary" of a transaction. With today's trading patterns becoming more and more diverse and complex, it is difficult to accurately capture the beneficiaries from a static perspective. But it is clear that we cannot easily judge from the direct beneficiaries of the transaction that there is not necessarily an equilateral mark between the direct beneficiary and the beneficiary. Combined with the relevant provisions of the State Administration of Taxation No. 9 announcement and the above three common issues, the author suggests that the relevant enterprises correctly apply the rules of adjudication in accordance with the rules, in order to better enjoy the treatment of tax agreements.

\section{A. Grasping the New Standards and Building a Compliance Organization Structure}

Announcement No. 9 extends the scope of application of the safe harbor of the dividend terms from listed companies to listed companies, governments and individuals, and stipulates that if the applicant does not comply with the safe harbor rules and is still unable to be identified as the beneficial owner after comprehensive analysis of the multifactor factors, the benefit penetration of the investment chain may be implemented, i.e. when the subsidiary does not meet the test of the beneficial owner, It is allowed to penetrate the parent company through the benefit of the investment chain, and according to the economic essence of the investment chain, the expansion of the identification of the beneficial owner is realized, which is beneficial to the residents' 
taxpayers to enjoy the treatment of the tax agreement. Relevant taxpayers can fully grasp the new criteria for the identification of beneficial owners, combined with their own actual business situation, build a compliance organization structure, and fully enjoy the policy dividends.

\section{B. Abiding by the New Requirements and Attaching Importance to the Substance of the Light Form}

While bringing policy dividends to taxpayers, Announcement 9 puts new demands on taxpayers, putting more emphasis on substance over form by introducing the "primary purpose test" (PPT) rule and the "interest limit" rule (LOB). For the first time, the concept of derivative benefit testing in LOB rules is used to put forward higher requirements for the substantive activities of relevant taxpayers. Multinational enterprises need to comply with the new requirements of Announcement No. 9, in the design of cross-border organizational structure, fully consider the essence of business operations, in accordance with the requirements of substance over form, and reduce the risk of tax-related.

\section{Grasping the New Spirit and Enhancing the Tax Processing Capacity}

The implementation of Proclamation No. 9 proclaims the Notice of the State Administration of Taxation on how to understand and identify the "beneficial owners" in the tax agreement (State Tax Letter (2009) No. 601) and the Notice of the State Administration of Taxation on the Identification of "Beneficial Owners" in the Tax Agreement" (The State Administration of Taxation announced No. 30 of 2012) leaving the historical stage of international taxation and ushering in a new era of identification of beneficial owners in China. Multinational enterprises should further optimize the internal hierarchy of the Group, in the process of crossborder production and operation, improve the overall taxrelated matters of the enterprise compliance, should not deliberately pursue cross-border tax revenue, in order to reduce the risk of abuse of tax agreements.

\section{CONCLUSION}

To date, the international tax law on the "beneficial owner" of the judgment due to the differences in national laws remains indifferent. It is believed that when the State party differs in its judgment of "beneficial owner" in accordance with the domestic law of the two parties, the meaning of international unity should be adopted. China's relevant laws and regulations should also conform to the international consensus, in order to avoid international double taxation, reduce tax disputes with the Parties.

\section{ACKNOWLEDGMENT}

This paper belongs to the project of the Fund Project "Fund Project Type: "Fujian Jiangxia College Horizontal Project"; Fund project number: JXH2019001; Fund Project Name: Research on Enterprise Financial Specification Reorganization Based on Tax Auditing Perspective".

\section{REFERENCES}

[1] China has signed 109 tax agreements and 102 have been put into effect. https://news.sina.com.cn/o/2018-11-30/docihmutuec5006183.shtml.30

[2] Yang Chong. "Beneficiaries" Determination of The Application Study of International Anti-Avoidance in China. November 2018.

[3] Xu Yig. Why were the applications of these enterprises rejected? https://mp.weixin.qq.com/s?biz?biz?mzA4ODMwMDkzMw\%3D\%3 D-idx-1-mid-2670458841-sn1423deff61cf8d45078455122ccee80.2018. 